\title{
Effects of time and sampling location on concentrations of $\beta$-hydroxybutyric acid in dairy cows
}

\author{
A. Mahrt, O. Burfeind, and W. Heuwieser ${ }^{1}$ \\ Clinic for Animal Reproduction, Faculty of Veterinary Medicine, Freie Universität Berlin, Koenigsweg 65, 14163 Berlin, Germany
}

\begin{abstract}
Two trials were conducted to examine factors potentially influencing the measurement of blood $\beta$-hydroxybutyric acid (BHBA) in dairy cows. The objective of the first trial was to study effects of sampling time on BHBA concentration in continuously fed dairy cows. Furthermore, we determined test characteristics of a single BHBA measurement at a random time of the day to diagnose subclinical ketosis considering commonly used cut-points (1.2 and $1.4 \mathrm{mmol} / \mathrm{L})$. Finally, we set out to evaluate if test characteristics could be enhanced by repeating measurements after different time intervals. During 4 herd visits, a total of 128 cows ( 8 to $28 \mathrm{~d}$ in milk) fed 10 times daily were screened at $0900 \mathrm{~h}$ and preselected by BHBA concentration. Blood samples were drawn from the tail vessels and BHBA concentrations were measured using an electronic BHBA meter (Precision Xceed, Abbott Diabetes Care Ltd., Witney, UK). Cows with BHBA concentrations $\geq 0.8 \mathrm{mmol} / \mathrm{L}$ at this time were enrolled in the trial $(\mathrm{n}=92)$. Subsequent BHBA measurements took place every $3 \mathrm{~h}$ for a total of 8 measurements during $24 \mathrm{~h}$. The effect of sampling time on BHBA concentrations was tested in a repeated-measures ANOVA repeating sampling time. Sampling time did not affect BHBA concentrations in continuously fed dairy cows. Defining the average daily BHBA concentration calculated from the 8 measurements as the gold standard, a single measurement at a random time of the day to diagnose subclinical ketosis had a sensitivity of 0.90 or 0.89 at the 2 BHBA cut-points $(1.2$ and $1.4 \mathrm{mmol} / \mathrm{L})$. Specificity was 0.88 or 0.90 using the same cut-points. Repeating measurements after different time intervals improved test characteristics only slightly. In the second experiment, we compared BHBA concentrations of samples drawn from 3 different blood sampling locations (tail vessels, jugular vein, and mammary vein) of 116 lactating dairy cows. Concentrations of BHBA differed in samples from the 3 sampling locations. Mean BHBA
\end{abstract}

Received June 4, 2013

Accepted September 12, 2013.

${ }^{1}$ Corresponding author: w.heuwieser@fu-berlin.de concentration was $0.3 \mathrm{mmol} / \mathrm{L}$ lower when measured in the mammary vein compared with the jugular vein and $0.4 \mathrm{mmol} / \mathrm{L}$ lower in the mammary vein compared with the tail vessels. We conclude that to measure BHBA, blood samples of continuously fed dairy cows can be drawn at any time of the day. A single measurement provides very good test characteristics for on-farm conditions. Blood samples for BHBA measurement should be drawn from the jugular vein or tail vessels; the mammary vein should not be used for this purpose.

Key words: subclinical ketosis, $\beta$-hydroxybutyric acid, diurnal rhythm, herd health

\section{INTRODUCTION}

During the transition period, dairy cows have to adapt to increased energy demands resulting from late gestation and the onset of lactation after calving (Goff and Horst, 1997) while DMI is reduced. Subsequently, a negative energy balance (NEB) occurs in most cows (Herdt, 2000). The resulting lipolysis causes elevated levels of serum NEFA and, if their complete oxidation in the liver fails due to an overload, levels of serum ketone bodies (i.e., BHBA, acetoacetate, acetone) also increase (Krebs, 1966; Herdt, 2000). Subclinical ketosis (SCK) is one of the most important metabolic diseases in high-producing dairy cattle and is defined as the presence of elevated concentrations of circulating ketone bodies without the appearance of clinical signs (Andersson, 1988). First-parity heifers and second-parity cows have a reduced risk for SCK compared with older cows (Duffield et al., 1998). Subclinical ketosis causes economic losses (Duffield, 2000; Geishauser et al., 2001; Hogeveen, 2012) and increases the risk of subsequent diseases; for example, displaced abomasum (LeBlanc et al., 2005; Duffield et al., 2009), metritis (Duffield et al., 2009), clinical ketosis (Duffield et al., 2009; Seifi et al., 2011), and lameness (Suthar et al., 2013). It is well documented that SCK negatively affects reproductive performance (Koller et al., 2003; Walsh et al., 2007a,b; Ospina et al., 2010b) and milk yield (Ospina et al., 2010b). Roberts et al. (2012) found an increased risk of culling within the first 60 DIM for cows with elevated BHBA concentrations. 
Subclinical ketosis has been described as a threshold disease (Oetzel, 2004) and the diagnosis depends on a cut-point (i.e., 1.2 to $1.4 \mathrm{mmol} / \mathrm{L}$; Duffield et al., 1998; Enjalbert et al., 2001; Oetzel, 2004). Therefore, diagnostic methods have to determine the concentration of ketone bodies semiquantitatively or quantitatively in different body fluids. Measurement of blood BHBA concentration in laboratories is the gold standard test for diagnosis of SCK (Oetzel, 2004). In addition, a range of cow-side ketone body tests is available. Several semiquantitative urine or milk tests have been evaluated (Geishauser et al., 1998, 2000; Carrier et al., 2004). An electronic patient-side test measuring whole-blood BHBA concentration (Precision Xceed, Abbott Diabetes Care Ltd., Witney, UK) was recently validated for use in dairy cows (Iwersen et al., 2009) and sheep (Panousis et al., 2012). Its main advantages include an immediate quantitative measurement with high sensitivity and specificity without logistical efforts for laboratory analysis (e.g., cooling, centrifugation, or shipping).

Frequently used cut-points for the concentration of BHBA in serum of dairy cows are $1.2 \mathrm{mmol} / \mathrm{L}$ (Duffield et al., 1998; Enjalbert et al., 2001; Suthar et al., 2013) and $1.4 \mathrm{mmol} / \mathrm{L}$ (Geishauser et al., 2001; Oetzel, 2004). Such cut-points, however, are biased by sampling time relative to calving and cut-point criteria such as disease prevalence, milk production, or both (Duffield et al., 2009). Several authors recommend strategic programs for monitoring dairy herds for magnitude of NEB, SCK, and subsequent diseases (Duffield, 2000; Oetzel, 2004; LeBlanc et al., 2005).

To implement screening protocols with reliable and repeatable results, information on factors potentially influencing the measurement of BHBA is essential. Oetzel (2004) supposed that the blood sampling location affects the BHBA concentration. He recommended that blood samples to measure BHBA concentration should not be collected from the mammary vein (V. epigastrica cranialis superficialis) because the mammary gland is able to utilize BHBA as an energy source (Kronfeld et al., 1968), which might affect venous BHBA concentration. One previous study observed 9.3\% lower BHBA concentrations in blood samples obtained from the mammary vein compared with the jugular vein (Redetzky et al., 2003). Sample size, however, was limited $(\mathrm{n}=12)$ and the difference was not significant in this study. Wilhelm et al. (2013) also found higher concentrations of BHBA in samples taken from the jugular vein and saphenous veins compared with the mammary vein in lactating dairy cows. However, the tail vessels were not considered in either of these trials. Overall, there is a dearth of information on the effect of commonly used sampling locations (i.e., jugular vein, mammary vein, tail vessels) on BHBA concentrations.

Furthermore, several authors have reported effects of diurnal patterns (Andersson, 1988; Plaizier et al., 2005) or sampling time relative to feeding (Oetzel, 2004; Nikkhah et al., 2008; Quiroz-Rocha et al., 2010) on blood BHBA concentrations. The diurnal rhythm of BHBA was found to be associated with feeding frequency (Eicher et al., 1999). The latter authors recommended collection of 2 samples (morning and afternoon) to enhance the assessment of metabolic situations. An increased feeding frequency reduces both the maximum concentration and the amplitude of daily fluctuations in concentrations of BHBA (Sutton et al., 1988). Information is lacking on diurnal patterns of BHBA concentration under conditions of a continuous TMR feeding regimen and how sampling time and frequency of testing affect test characteristics (i.e., sensitivity and specificity). Therefore, the overall objective of this study was to analyze diurnal effects on BHBA concentrations for cows with a continuous TMR feeding. Specifically, we set out to (1) study effects of sampling time on BHBA concentration in continuously TMR-fed dairy cows, (2) determine test characteristics (sensitivity, specificity, positive and negative predictive values) of a single BHBA measurement at a random time of the day to diagnose SCK, (3) evaluate if test characteristics can be enhanced by repeating measurements, and (4) compare BHBA concentrations of samples drawn from 3 different blood sampling locations.

\section{MATERIALS AND METHODS}

Two trials were conducted between April and July 2012 on a commercial dairy farm (Sachsen-Anhalt, Germany) that housed approximately 1,200 HolsteinFriesian dairy cows with an average annual milk yield of $10,701 \mathrm{~kg}$ ( $4.04 \%$ fat and $3.35 \%$ protein). Cows were housed in a freestall barn with slatted floors and cubicles equipped with rubber mats. Cows were fed a TMR consisting of $38.5 \%$ corn silage, $35.9 \%$ concentrate mineral mix, $22.5 \%$ grass silage, and $3.1 \%$ barley straw on a $\mathrm{DM}$ basis $\left(\mathrm{NE}_{\mathrm{L}}=7.15 \mathrm{MJ} / \mathrm{kg}\right.$ of $\left.\mathrm{DM}\right)$. Feed was delivered over a conveyer belt system 10 times per day. Cows were milked 3 times a day at approximately 0630, 1430, and $2230 \mathrm{~h}$ in a 52-stall rotary milking parlor (Lemmer-Fullwood GmbH, Lohmar, Germany).

In both trials, BHBA was measured with an electronic BHBA meter (Precision Xceed, Abbott Diabetes Care Ltd.) that has been used in multiple research trials (Iwersen et al., 2009; Endecott et al., 2012; McArt et al., 2012). The test system consists of the handheld device and test strips, which are equipped with an 
electrochemical reaction field at the tip. Results are displayed in millimoles per liter.

The purpose of trial 1 was to evaluate the effects of sampling time on BHBA concentrations. For this trial, the farm was visited 4 times at intervals of $3 \mathrm{wk}$ each. All multiparous cows within 8 to 28 DIM at the time of a visit were considered eligible and a total of 128 cows were screened. Initial screening took place at approximately $0900 \mathrm{~h}$. Blood samples were collected from the tail vessels using a 2-mL syringe (Henry Schein Inc., Melville, NY) and a 23-gauge needle (Sterican, B. Braun, Melsungen, Germany). Blood was analyzed immediately after sampling by applying a small amount of blood from the syringe onto the test strip. Displayed BHBA concentrations were recorded. Cows with a BHBA concentration $\geq 0.8 \mathrm{mmol} / \mathrm{L}$ at $0900 \mathrm{~h}$ were enrolled in the trial. Subsequent BHBA measurements took place every $3 \mathrm{~h}$ for a total of $24 \mathrm{~h}$ (i.e., 1200 , 1500, 1800, 2100, 2400, 0300, and $0600 \mathrm{~h}$ ). A total of 92 cows (DIM: $18 \pm 6$, parity: $3.2 \pm 1.2$ ) met the inclusion criteria (i.e., multiparous cow, DIM 8 to 28 , BHBA concentration $\geq 0.8 \mathrm{mmol} / \mathrm{L}$ at $0900 \mathrm{~h}$ ) and were used for the analyses.

Trial 2 was conducted to compare BHBA concentrations of samples drawn from 3 different blood sampling locations. Blood samples were taken from 116 postpartum cows (DIM: $19 \pm 13$, parity: $2.9 \pm 1.2$ ). Samples were taken within $3 \pm 1 \mathrm{~min}$ in each cow from the tail vessels (A./V. coccygea), the jugular vein (V. jugularis), and the mammary vein (V. epigastrica cranialis superficialis) using an evacuated tube system (Vacuette, Greiner bio one, Kremsmünster, Austria). Whole blood samples were analyzed immediately after collection using the Precision Xceed handheld meter and test strips by connecting the reaction field at the end of the test strip with the surface of the blood. Displayed BHBA concentrations were recorded.

All data were statistically analyzed with SPSS (version 19.0, SPSS Inc., Munich, Germany). The effect of sampling time on measured BHBA concentrations was tested in a repeated-measures ANOVA repeating sampling time. In a second approach, test characteristics of a single BHBA measurement at a random time of the day to diagnose SCK were determined using 2 different cut-points (1.2 and $1.4 \mathrm{mmol} / \mathrm{L})$ that are commonly used to define SCK. The average daily BHBA concentration calculated from the 8 measurements was used as the gold standard to define a cow as healthy or as having SCK. Cows were defined as healthy when the average daily BHBA concentration was lower than the respective cut-point $(1.2$ or $1.4 \mathrm{mmol} / \mathrm{L})$ and as having SCK when the cut-point was reached. Sensitivity was calculated as the proportion of measurements that correctly diagnosed a cow with SCK as having SCK (i.e., BHBA concentration measured at the particular time of the day was equal to or above the cut-point considered and the daily average BHBA concentration was equal to or above the cut-point considered). Specificity was calculated as the proportion of measurements that correctly diagnosed a cow without SCK as healthy (BHBA concentration measured at the particular time of the day was below the cut-point considered and the daily average BHBA concentration was below the cutpoint considered). The positive predictive value was determined as the proportion of measurements equal to or greater than the cut-point considered at which the cow was truly suffering from SCK (daily average BHBA concentration was equal to or above the cut-point considered). The negative predictive value was calculated as the proportion of measurements below the cut-point considered at which the cow was truly healthy (daily average BHBA concentration was below the cut-point considered). A second analysis was conducted to study if the test characteristics increased in marginal cases (i.e., BHBA concentrations from 1.0 to $1.6 \mathrm{mmol} / \mathrm{L}$ ) using values obtained by repeated measurements instead of a single measurement. Cows having BHBA concentrations $<1.0 \mathrm{mmol} / \mathrm{L}$ or $>1.6 \mathrm{mmol} / \mathrm{L}$ at the given time of the day were classified as clearly healthy or as clearly subclinically ketotic, respectively, and the initial measured concentration was used for analysis. For measurements with marginal BHBA concentrations at the first sampling (i.e., 1.0 to $1.6 \mathrm{mmol} / \mathrm{L}$ ), a second measurement 3, $6,9,12,15,18$, or $21 \mathrm{~h}$ later was used and the average with the initial measurement calculated. Subsequently, this average was used to classify a cow as healthy or suffering from SCK. Test characteristics (sensitivity, specificity, positive and negative predictive values) were calculated as described above. Again, the average daily BHBA concentration was used as the gold standard to define a cow as healthy or as having SCK.

Relationships between BHBA concentrations measured at the 3 different sampling locations were calculated with Pearson correlation. The differences between the sampling locations were determined with a one-way ANOVA. Mean differences were determined with the least significant difference post hoc test. Because a comparison of clinical measurements can be inappropriate using Pearson correlation, the agreement between the 3 sampling locations was graphically analyzed with MedCalc (version 12.0.3.0, MedCalc Software bvba, Ostend, Belgium) as described by Bland and Altman (1986).

\section{RESULTS}

\section{Trial 1}

Of 128 eligible cows screened before the trial, 92 showed BHBA concentrations $\geq 0.8 \mathrm{mmol} / \mathrm{L}$ at the first 
Table 1. Test characteristics of single and repeated measurements of BHBA concentration after different time intervals to diagnose subclinical ketosis (SCK) in dairy cows ${ }^{1}$

\begin{tabular}{|c|c|c|c|c|c|c|c|c|}
\hline $\begin{array}{l}\text { Threshold and } \\
\text { test characteristics }\end{array}$ & $\begin{array}{c}\text { Single } \\
\text { measurement }\end{array}$ & \multicolumn{7}{|c|}{ Time interval between 2 repeated measurements } \\
\hline \multicolumn{9}{|l|}{$1.2 \mathrm{mmol} / \mathrm{L}$} \\
\hline Specificity & 0.88 & 0.94 & 0.96 & 0.97 & 0.97 & 0.96 & 0.96 & 0.98 \\
\hline Positive predictive value & 0.91 & 0.95 & 0.97 & 0.98 & 0.97 & 0.97 & 0.97 & 0.98 \\
\hline Negative predictive value & 0.87 & 0.89 & 0.89 & 0.89 & 0.89 & 0.88 & 0.89 & 0.87 \\
\hline \multicolumn{9}{|l|}{$1.4 \mathrm{mmol} / \mathrm{L}$} \\
\hline Specificity & 0.90 & 0.92 & 0.94 & 0.92 & 0.92 & 0.94 & 0.94 & 0.96 \\
\hline Positive predictive value & 0.86 & 0.88 & 0.92 & 0.89 & 0.89 & 0.91 & 0.91 & 0.94 \\
\hline Negative predictive value & 0.92 & 0.94 & 0.95 & 0.95 & 0.95 & 0.95 & 0.94 & 0.93 \\
\hline
\end{tabular}

${ }^{1}$ Every measurement of each cow (8 measurements per cow) was tested for SCK. Cows with values $<1.0$ mmol/L were classified as clearly healthy at that time and cows with values $>1.6 \mathrm{mmol} / \mathrm{L}$ were classified as clearly subclinically ketotic at that time. Cows with values between $1.0 \mathrm{mmol} / \mathrm{L}$ and $1.6 \mathrm{mmol} / \mathrm{L}$ were classified as marginal. In these cases, another measurement at $3,6,9,12,15,18$, or $21 \mathrm{~h}$ was considered and the average with the initial measurement calculated. Subsequently, this average was used to classify a cow as healthy or suffering from SCK. To calculate test characteristics, the average daily BHBA concentration calculated from the 8 measurements was used as the gold standard to define a cow as healthy or as having SCK.

measurement at $0900 \mathrm{~h}$ and were included in the trial. Of all cows, $52(40.6 \%)$ were diagnosed with SCK using a cut-point of $1.2 \mathrm{mmol} / \mathrm{L}$. Increasing the cut-point to $1.4 \mathrm{mmol} / \mathrm{L}$ reduced the number of cows diagnosed with SCK to 38 (29.7\%).

Sampling time did not affect BHBA concentrations in continuously fed dairy cows $(P=0.23$; Figure 1$)$. Test characteristics (sensitivity, specificity, positive and negative predictive values) of a single measurement of BHBA concentration at a random time of the day to diagnose SCK, using 2 different cut-points, are shown in Table 1. Furthermore, test characteristics using repeated measurements after different time intervals $(3$, $6,9,12,15,18$, and $21 \mathrm{~h}$ ) in marginal cases (BHBA

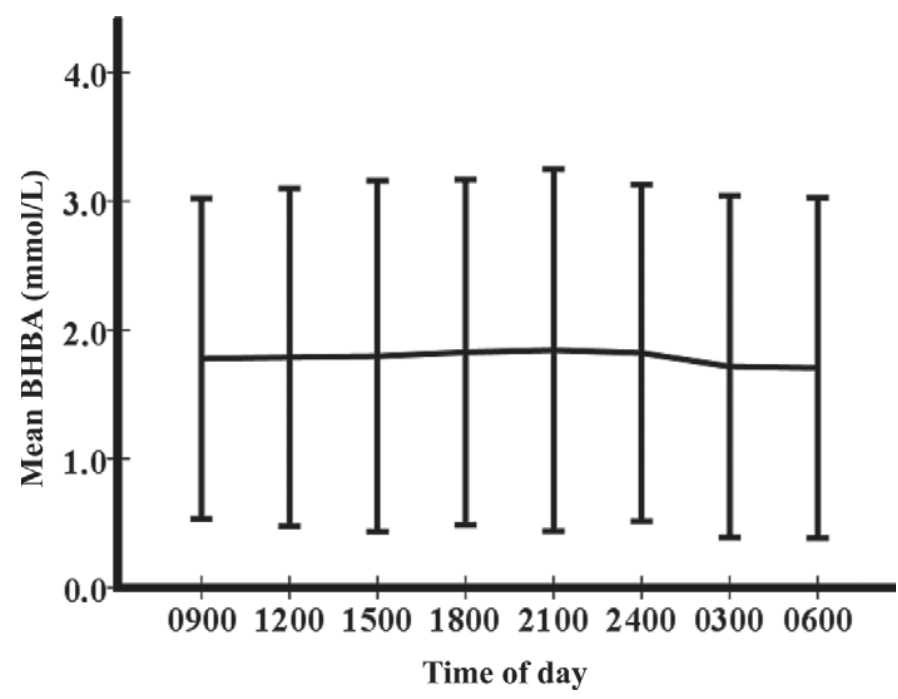

Figure 1. Mean diurnal rhythm and standard deviation of concentrations of BHBA in 92 multiparous dairy cows at $18 \pm 6$ DIM. concentrations from 1.0 to $1.6 \mathrm{mmol} / \mathrm{L}$ ) are shown (Table 1).

\section{Trial 2}

A total of 116 postpartum cows were included in the trial. Considering BHBA concentrations measured in blood samples drawn from the tail vessels, 54 cows $(46.6 \%)$ were diagnosed with SCK using a cut-point of $1.2 \mathrm{mmol} / \mathrm{L}$. Using a cut-point of $1.4 \mathrm{mmol} / \mathrm{L}$ reduced the number of cows diagnosed with SCK to 38 (32.8\%).

Concentrations of BHBA differed when comparing samples from the 3 sampling locations (tail vessels: 1.6 $\pm 1.2 \mathrm{mmol} / \mathrm{L}$, jugular vein: $1.5 \pm 1.2 \mathrm{mmol} / \mathrm{L}$, mammary vein: $1.2 \pm 1.1 \mathrm{mmol} / \mathrm{L} ; P=0.03)$. Mean BHBA concentration was $0.3 \mathrm{mmol} / \mathrm{L}$ lower when measured in the mammary vein compared with the jugular vein $(P=0.03$; Figure 2A). Mean BHBA concentration was $0.4 \mathrm{mmol} / \mathrm{L}$ lower when measured in the mammary vein compared with the tail vessels $(P=0.02$; Figure $2 \mathrm{~B})$. Measured BHBA concentration did not differ significantly between the jugular vein and the tail vessels $(P=0.82$; Figure $2 \mathrm{C})$. Concentrations of BHBA were strongly correlated for every combination of sampling locations (jugular vein and mammary vein: $r=0.98$; jugular vein and tail vessels: $r=0.99$, mammary vein and tail vessels: $\mathrm{r}=0.99 ; P<0.05)$.

\section{DISCUSSION}

In both trials conducted during this study, the prevalence of SCK was higher than the range (11.2 to $36.6 \%$ at a cut-point of $1.2 \mathrm{mmol} / \mathrm{L}$ ) described in previous studies (McArt et al., 2012; Suthar et al., 2013). For 
the first trial, one possible reason for this difference might be the selection of multiparous cows (parity 3.2 \pm 1.2 ) only. First-parity heifers and second-parity cows are at lower risk of developing SCK (Duffield et al., 1998); thus, a higher prevalence of SCK is plausible in a group consisting of multiparous cows only. For the second trial, only 10 primiparous and 106 multiparous cows (parity $2.9 \pm 1.2$ ) were enrolled, which likewise increased the prevalence of SCK. Multiple factors have been identified that influence the development of SCK, leading to variation in prevalence rates between farms and countries (Suthar et al., 2013). Several authors found associations between ketosis and transition cow management, feeding strategies, genetic variation, milk yield, concomitant diseases, and body condition score patterns during the transition period and early lactation (Oetzel, 2007; Roche et al., 2009; van der Drift et al., 2012).

\section{Effects of Sampling Time on BHBA Concentration}

Evidence suggests that BHBA concentration in dairy cows can be influenced by time of sampling relative to feeding time (Wylie et al., 2008; Quiroz-Rocha et al., 2010) and can be subject to diurnal variations (Sutton et al., 1988; Eicher et al., 1999; Blum et al., 2000; Nielsen et al., 2003; Plaizier et al., 2005; Meier et al., 2010). In most of these studies, BHBA concentrations showed postprandial increases (Sutton et al., 1988; Blum et al., 2000; Wylie et al., 2008), which can be explained by butyrate metabolism of the rumen epithelium after feed intake (Pennington, 1952; Reynolds, 2002). Interestingly, this effect was higher when feeding once at $2100 \mathrm{~h}$ instead of once at $0900 \mathrm{~h}$ (Nikkhah et al., 2008). The authors proposed that this effect of feed delivery time might be caused by an increase in feed intake when cows were fed at $2100 \mathrm{~h}$ compared with $0900 \mathrm{~h}$, which might have increased BHBA synthesis in the rumen wall.

An effect of sampling time on BHBA concentrations of dairy cows was not found in our study. A probable explanation for this different outcome compared with other investigations is the implementation of different feeding strategies within these trials. Cows in other studies received component feeding (Sutton et al., 1988; Eicher et al., 1999; Blum et al., 2000; Wylie et al., 2008) or, in case of a TMR feeding, were fed only once or twice daily (Plaizier et al., 2005; Nikkhah et al., 2008; Meier et al., 2010; Quiroz-Rocha et al., 2010), whereas cows in our study had continuous access to freshly delivered TMR.

Sutton et al. (1988) determined the amplitude of diurnal patterns of BHBA concentration to be dependent on feeding frequency in component-fed cows. More frequent feeding reduced both the maximum concentrations and daily variations in BHBA. Eicher et al. (1999) also found significantly different patterns of diurnal variations of BHBA concentrations in 2 herds with different concentrate feeding frequencies. A higher feeding frequency with small amounts of concentrates in one herd effected a constant concentration of BHBA. The other herd was fed concentrates in larger amounts only twice a day and showed significant differences between morning and afternoon BHBA concentrations. A high feeding frequency of concentrates has been identified as an important factor in the prevention of hyperketonemia in component-fed dairy cows (Gustafsson et al., 1995).

Modern feeding strategies for dairy cows usually imply feeding a TMR diet (VandeHaar and St-Pierre, 2006; Winsten et al., 2010). Diurnal feed alley attendance patterns and feeding behavior of TMR fed lactating dairy cows are affected by return from milking, feed push-ups, and, particularly, fresh feed delivery (DeVries et al., 2003; DeVries and von Keyserlingk, 2005; Mäntysaari et al., 2006). An increase in daily feeding time, as well as a more even distribution of feeding time during the day, was found in dairy cows when increasing the TMR feeding frequency (DeVries et al., 2005). These findings might explain a more continuous BHBA metabolism and consequently the absence of diurnal patterns, as described in this study. Our BHBA data underline the importance of feeding strategies that assure constant access to freshly delivered TMR.

To our knowledge, this is the first trial studying cows preselected by BHBA concentration as being at risk for SCK. Other studies did not implement such an inclusion criterion for the enrollment of study animals; consequently, most cows investigated had BHBA concentrations below current accepted cut-points for diagnosis of SCK.

\section{Test Characteristics of a Single Measurement of BHBA at a Random Time of the Day}

Eicher et al. (1999) recommended standardizing the time after feeding for sample collection and suggested 4 to $5 \mathrm{~h}$ after the beginning of feeding as a proper sampling time for testing for metabolic disorders. Although plausible, this hypothesis was not tested. On the contrary, the time before the morning feeding has been described as being the most useful to test cows in early lactation for parameters of NEB (Wylie et al., 2008). In the latter study, however, only primiparous cows were used and they were fed only once daily. The scope of our study was to investigate diurnal effects in multiparous cows under conditions of a continuous TMR feeding. 
A

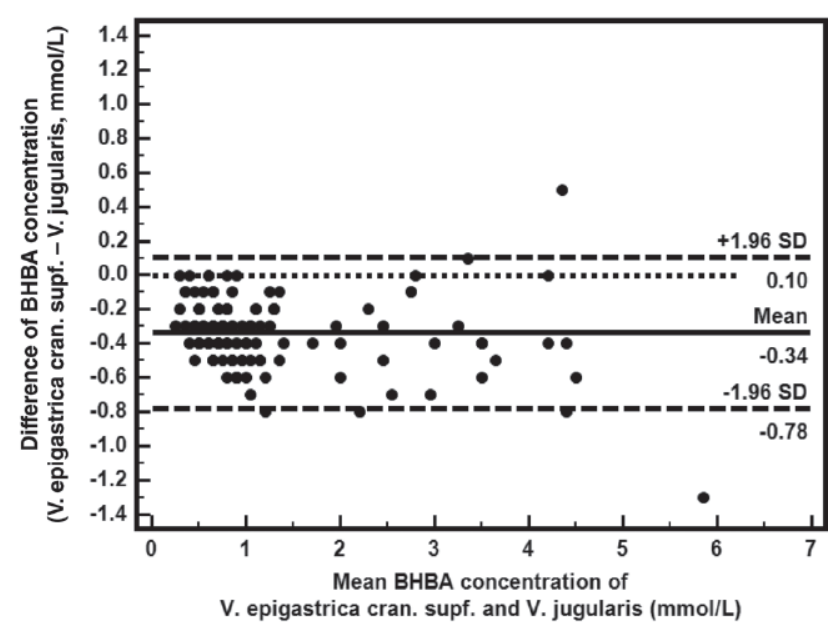

B

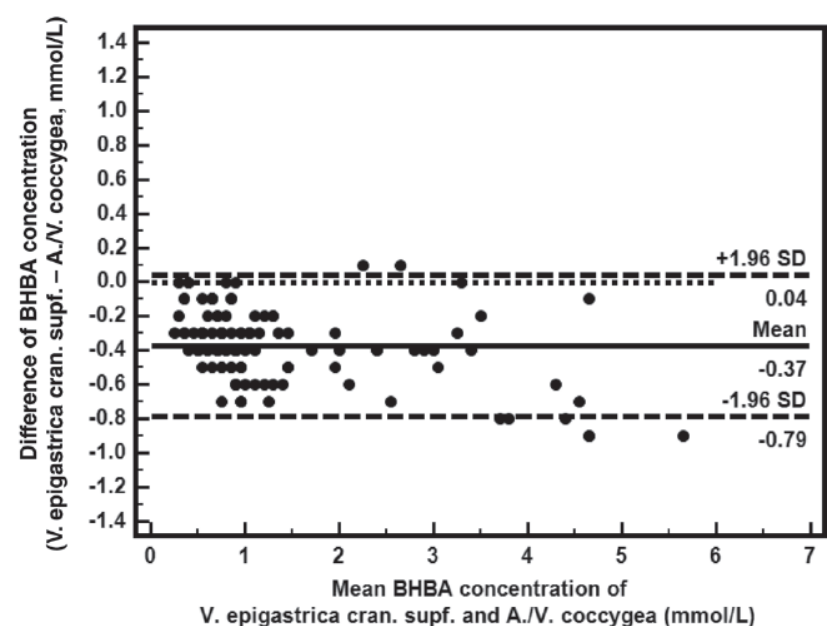

C

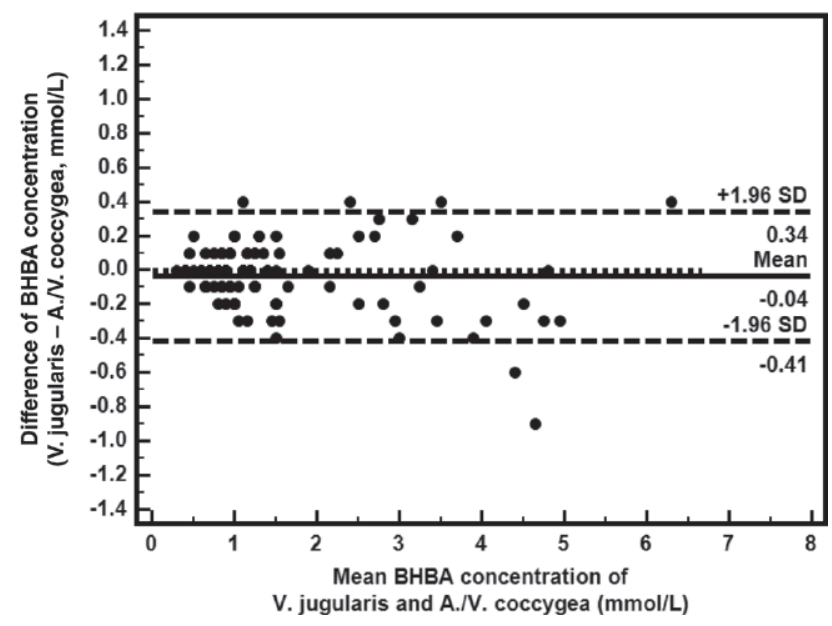

Figure 2. Differences of BHBA concentrations measured in blood samples taken from 3 different sampling locations: tail vessels (A./V. coccygea), jugular vein (V. jugularis), and mammary vein (V. epigastrica cranialis superficialis).
A single measurement of BHBA concentration at a random time of the day enabled the correct classification of a cow as suffering from SCK with a sensitivity of $0.90(\geq 1.2 \mathrm{mmol} / \mathrm{L})$ or $0.89(\geq 1.4 \mathrm{mmol} / \mathrm{L})$, respectively. Specificity was 0.88 or 0.90 using the same cut-points. These test characteristics can be considered as very good for a cow-side test. Based on our results, screening dairy cows for SCK under conditions of a continuous TMR feeding regimen can be integrated in a fresh cow protocol at any time of the day.

\section{Test Characteristics of Repeated Measurements}

Eicher et al. (1999) presumed the collection of 2 samples (morning and afternoon) to be more informative regarding the metabolic status of a herd. Sensitivity and specificity of repeated measurements after different time intervals to diagnose SCK (Table 1), however, increased only slightly compared with a single measurement at a random time of the day. Hence, from our data, the preferred sampling interval can be chosen. As these improvements are practically negligible, we feel that test characteristics of a single measurement are sufficient for on-farm situations.

\section{BHBA Concentrations of Samples Drawn from 3 Different Blood Sampling Locations}

It has been reported that blood samples for measurement of BHBA concentration should not be collected from the mammary vein (Oetzel, 2004; Wilhelm et al., 2013) but instead from the tail vessels (LeBlanc, 2006). It is known that the lactating mammary gland extracts BHBA as a precursor for milk fat from the blood, leading to an arterio-venous difference in BHBA concentration (Kronfeld et al., 1968; Guinard-Flament et al., 2011). The most important factor affecting the extent of this uptake is the arterial BHBA concentration (Miller et al., 1991).

Wilhelm et al. (2013) compared BHBA concentrations in blood samples taken from 4 different sampling locations (mammary vein, jugular vein, and left and right V. saphena externa lateralis). The authors found higher concentrations of BHBA in samples taken from the jugular vein and Vv. saphenae compared with the mammary vein in lactating dairy cows. Redetzky et al. (2003) also found higher levels of BHBA in blood drawn from the jugular vein compared with the mammary vein in lactating dairy cows. Interestingly, BHBA concentrations in nonlactating cows showed an inverse relationship (Wilhelm et al., 2013). The authors speculated that different BHBA consumption rates in the tissues drained by these veins (i.e., especially brain and udder) caused this difference. However, the tail ves- 
sels were not included in both of these comparisons, although this sampling location has practical benefits (e.g., easier handling) and has been used in previous research trials (Enjalbert et al., 2001; Iwersen et al., 2009; McArt et al., 2012).

Comparing the mammary vein, jugular vein, and tail vessels, we found significant differences in blood BHBA concentrations between samples drawn from the mammary vein and both of the other locations. Concentrations of BHBA in blood samples taken from the mammary vein were 0.3 and $0.4 \mathrm{mmol} / \mathrm{L}$ lower compared with samples taken from the jugular vein and tail vessels, respectively. No significant difference was observed between samples taken from the jugular vein and tail vessels. Therefore, we recommend the use of the jugular vein or tail vessels as a sampling location for BHBA measurements.

\section{CONCLUSIONS}

Screening dairy cows for SCK under conditions of continuous TMR feeding can be performed at any time of the day. A single measurement provides very good test characteristics for on-farm conditions. Repeated measurements after different time intervals improved test characteristics only slightly in our study. The jugular vein or tail vessels should be used as blood sampling locations for measurement of BHBA. Blood drawn from the mammary vein contains lower BHBA concentrations compared with the jugular vein or tail vessels.

\section{ACKNOWLEDGMENTS}

The authors thank the owners, the herdswoman, and the staff of the participating farm. Special thanks go to Anne Rees for her support during sample collection.

\section{REFERENCES}

Andersson, L. 1988. Subclinical ketosis in dairy cows. Vet. Clin. North Am. Food Anim. Pract. 4:233-251.

Bland, J. M., and D. G. Altman. 1986. Statistical methods for assessing agreement between two methods of clinical measurement. Lancet 1:307-310.

Blum, J. W., R. M. Bruckmaier, P. Y. Vacher, A. Münger, and F. Jans. 2000. Twenty-four-hour patterns of hormones and metabolites in week 9 and 19 of lactation in high-yielding dairy cows fed triglycerides and free fatty acids. J. Vet. Med. A Physiol. Pathol. Clin. Med. 47:43-60.

Carrier, J., S. Stewart, S. Godden, J. Fetrow, and P. Rapnicki. 2004. Evaluation and use of three cowside tests for detection of subclinical ketosis in early postpartum cows. J. Dairy Sci. 87:3725-3735.

DeVries, T. J., and M. A. G. von Keyserlingk. 2005. Time of feed delivery affects the feeding and lying patterns of dairy cows. J. Dairy Sci. 88:625-631.

DeVries, T. J., M. A. G. von Keyserlingk, and K. A. Beauchemin. 2003. Short communication: Diurnal feeding pattern of lactating dairy cows. J. Dairy Sci. 86:4079-4082.
DeVries, T. J., M. A. G. von Keyserlingk, and K. A. Beauchemin. 2005. Frequency of feed delivery affects the behavior of lactating dairy cows. J. Dairy Sci. 88:3553-3562.

Duffield, T. 2000. Subclinical ketosis in lactating dairy cattle. Vet. Clin. North Am. Food Anim. Pract. 16:231-253.

Duffield, T. F., K. D. Lissemore, B. W. McBride, and K. E. Leslie. 2009. Impact of hyperketonemia in early lactation dairy cows on health and production. J. Dairy Sci. 92:571-580.

Duffield, T. F., D. Sandals, K. E. Leslie, K. Lissemore, B. W. McBride, J. H. Lumsden, P. Dick, and R. Bagg. 1998. Efficacy of monensin for the prevention of subclinical ketosis in lactating dairy cows. J. Dairy Sci. 81:2866-2873.

Eicher, R., A. Liesegang, E. Bouchard, and A. Tremblay. 1999. Effect of cow-specific factors and feeding frequency of concentrate on diurnal variations of blood metabolites in dairy cows. Am. J. Vet. Res. 60:1493-1499.

Endecott, R. L., S. H. Cox, C. M. Rubio, C. A. Löest, D. E. Hawkins, and M. K. Petersen. 2012. Effects of supplements with increasing glucogenic precursor content on reproduction and nutrient utilization in young postpartum range cows. Livest. Sci. 145:109-118.

Enjalbert, F., M. C. Nicot, C. Bayourthe, and R. Moncoulon. 2001. Ketone bodies in milk and blood of dairy cows: Relationship between concentrations and utilization for detection of subclinical ketosis. J. Dairy Sci. 84:583-589.

Geishauser, T., K. Leslie, D. Kelton, and T. Duffield. 1998. Evaluation of five cowside tests for use with milk to detect subclinical ketosis in dairy cows. J. Dairy Sci. 81:438-443.

Geishauser, T., K. Leslie, D. Kelton, and T. Duffield. 2001. Monitoring for subclinical ketosis in dairy herds. Comp. Contin. Educ. Vet. 23:65-71.

Geishauser, T., K. Leslie, J. Tenhag, and A. Bashiri. 2000. Evaluation of eight cow-side ketone tests in milk for detection of subclinical ketosis in dairy cows. J. Dairy Sci. 83:296-299.

Goff, J. P., and R. L. Horst. 1997. Physiological changes at parturition and their relationship to metabolic disorders. J. Dairy Sci. 80:1260-1268.

Guinard-Flament, J., S. Lemosquet, E. Delamaire, G. Le Bris, P. Lamberton, and C. Hurtaud. 2011. Alteration of the nutrient uptake by the udder over an extended milking interval in dairy cows. J. Dairy Sci. 94:5458-5468.

Gustafsson, A. H., L. Andersson, and U. Emanuelson. 1995. Influence of feeding management, concentrate intake and energy intake on the risk of hyperketonæmia in Swedish dairy herds. Prev. Vet. Med. 22:237-248.

Herdt, T. H. 2000. Ruminant adaptation to negative energy balance. Influences on the etiology of ketosis and fatty liver. Vet. Clin. North Am. Food Anim. Pract. 16:215-230.

Hogeveen, H. 2012. Costs of production diseases. Pages 36-42 in Proc. 27th World Buiatrics Congress, Lisbon, Portugal. LouresGráfica, Loures, Protugal.

Iwersen, M., U. Falkenberg, R. Voigtsberger, D. Forderung, and W. Heuwieser. 2009. Evaluation of an electronic cowside test to detect subclinical ketosis in dairy cows. J. Dairy Sci. 92:2618-2624.

Koller, A., M. Reist, J. W. Blum, and U. Kupfer. 2003. Time empty and ketone body status in the early postpartum period of dairy cows. Reprod. Domest. Anim. 38:41-49.

Krebs, H. A. 1966. The regulation of the release of ketone bodies by the liver. Adv. Enzyme Regul. 4:339-354.

Kronfeld, D. S., F. Raggi, and C. F. Ramberg Jr.. 1968. Mammary blood flow and ketone body metabolism in normal, fasted, and ketotic cows. Am. J. Physiol. 215:218-227.

LeBlanc, S. J. 2006. Monitoring programs for transition dairy cows. Pages 460-472 in Proc. 24th World Buiatrics Congress, Nice, France. World Association for Buiatrics.

LeBlanc, S. J., K. E. Leslie, and T. F. Duffield. 2005. Metabolic predictors of displaced abomasum in dairy cattle. J. Dairy Sci. $88: 159-170$.

Mäntysaari, P., H. Khalili, and J. Sariola. 2006. Effect of feeding frequency of a total mixed ration on the performance of high-yielding dairy cows. J. Dairy Sci. 89:4312-4320. 
McArt, J. A. A., D. V. Nydam, and G. R. Oetzel. 2012. Epidemiology of subclinical ketosis in early lactation dairy cattle. J. Dairy Sci. 95:5056-5066.

Meier, S., E. S. Kolver, G. A. Verkerk, and J. R. Roche. 2010. Effects of divergent Holstein-Friesian strain and diet on diurnal patterns of plasma metabolites and hormones. J. Dairy Res. 77:432-437.

Miller, P. S., B. L. Reis, C. C. Calvert, E. J. DePeters, and R. L. Baldwin. 1991. Patterns of nutrient uptake by the mammary glands of lactating dairy cows. J. Dairy Sci. 74:3791-3799.

Nielsen, N. I., K. L. Ingvartsen, and T. Larsen. 2003. Diurnal variation and the effect of feed restriction on plasma and milk metabolites in TMR-fed dairy cows. J. Vet. Med. A Physiol. Pathol. Clin. Med. 50:88-97.

Nikkhah, A., C. J. Furedi, A. D. Kennedy, G. H. Crow, and J. C. Plaizier. 2008. Effects of feed delivery time on feed intake, milk production, and blood metabolites of dairy cows. J. Dairy Sci. 91:4249-4260.

Oetzel, G. R. 2004. Monitoring and testing dairy herds for metabolic disease. Vet. Clin. North Am. Food Anim. Pract. 20:651-674.

Oetzel, G. R. 2007. Herd-level ketosis-Diagnosis and risk factors. Pages 67-91 in Proc. 40th Annu. Conf. Am. Assoc. Bovine Pract., Vancouver, Canada. Am. Assoc. Bovine Pract., Auburn, AL.

Ospina, P. A., D. V. Nydam, T. Stokol, and T. R. Overton. 2010b. Associations of elevated nonesterified fatty acids and $\beta$-hydroxybutyrate concentrations with early lactation reproductive performance and milk production in transition dairy cattle in the northeastern United States. J. Dairy Sci. 93:1596-1603.

Panousis, N., C. Brozos, I. Karagiannis, N. D. Giadinis, S. Lafi, and M. Kritsepi-Konstantinou. 2012. Evaluation of precision xceed ${ }^{\circledR}$ meter for on-site monitoring of blood $\beta$-hydroxybutyric acid and glucose concentrations in dairy sheep. Res. Vet. Sci. 93:435-439.

Pennington, R. J. 1952. The metabolism of short-chain fatty acids in the sheep. 1. Fatty acid utilization and ketone body production by rumen epithelium and other tissues. Biochem. J. 51:251-258.

Plaizier, J. C., A. M. Fairfield, P. A. Azevedo, A. Nikkhah, T. F. Duffield, G. H. Crow, R. Bagg, P. Dick, and B. W. McBride. 2005. Effects of monensin and stage of lactation on variation of blood metabolites within twenty-four hours in dairy cows. J. Dairy Sci. 88:3595-3602.

Quiroz-Rocha, G. F., S. J. LeBlanc, T. F. Duffield, B. Jefferson, D Wood, K. E. Leslie, and R. M. Jacobs. 2010. Short communication: Effect of sampling time relative to the first daily feeding on interpretation of serum fatty acid and $\beta$-hydroxybutyrate concentrations in dairy cattle. J. Dairy Sci. 93:2030-2033.

Redetzky, R. J. Hamann, and V. Krömker. 2003. Zum Einfluss des Blutentnahmeortes auf Parameter des Blutprofils bei hochleistenden Kühen. Tierarztl. Prax. Ausg. G Grosstiere Nutztiere 31:308-313.

Reynolds, C. K. 2002. Economics of visceral energy metabolism in ruminants: Toll keeping or internal revenue service? J. Anim. Sci. 80(E. Suppl.):E74-E84.
Roberts, T., N. Chapinal, S. J. LeBlanc, D. F. Kelton, J. Dubuc, and T. F. Duffield. 2012. Metabolic parameters in transition cows as indicators for early-lactation culling risk. J. Dairy Sci. 95:30573063.

Roche, J. R., N. C. Friggens, J. K. Kay, M. W. Fisher, K. J. Stafford, and D. P. Berry. 2009. Invited review: Body condition score and its association with dairy cow productivity, health, and welfare. J. Dairy Sci. 92:5769-5801.

Seifi, H. A., S. J. LeBlanc, K. E. Leslie, and T. F. Duffield. 2011 Metabolic predictors of post-partum disease and culling risk in dairy cattle. Vet. J. 188:216-220.

Suthar, V. S., J. Canelas-Raposo, A. Deniz, and W. Heuwieser. 2013. Prevalence of subclinical ketosis and relationships with postpartum diseases in European dairy cows. J. Dairy Sci. 96:2925-2938.

Sutton, J. D., I. C. Hart, S. V. Morant, E. Schuller, and A. D. Simmonds. 1988. Feeding frequency for lactating cows: Diurnal patterns of hormones and metabolites in peripheral blood in relation to milk-fat concentration. Br. J. Nutr. 60:265-274.

van der Drift, S. G. A., K. J. E. van Hulzen, T. W. Teweldemedhn R. Jorritsma, M. Nielen, and H. C. M. Heuven. 2012. Genetic and nongenetic variation in plasma and milk $\beta$-hydroxybutyrate and milk acetone concentrations of early-lactation dairy cows. J. Dairy Sci. 95:6781-6787.

VandeHaar, M. J., and N. St-Pierre. 2006. Major advances in nutrition: Relevance to the sustainability of the dairy industry. J. Dairy Sci. 89:1280-1291.

Walsh, R. B., D. F. Kelton, T. F. Duffield, K. E. Leslie, J. S. Walton, and S. J. LeBlanc. 2007a. Prevalence and risk factors for postpartum anovulatory condition in dairy cows. J. Dairy Sci. 90:315-324

Walsh, R. B., J. S. Walton, D. F. Kelton, S. J. LeBlanc, K. E. Leslie, and T. F. Duffield. 2007b. The effect of subclinical ketosis in early lactation on reproductive performance of postpartum dairy cows. J. Dairy Sci. 90:2788-2796.

Wilhelm, K., J. Wilhelm, and M. Fürll. 2013. Vergleichende Betrachtung ausgewählter Blutparameter von Hochleistungskühen bei unterschiedlichen Entnahmestellen. Tierarztl. Prax. Ausg. G Grosstiere Nutztiere 41:7-14.

Winsten, J. R., C. D. Kerchner, A. Richardson, A. Lichau, and J. M. Hyman. 2010. Trends in the northeast dairy industry: Large-scale modern confinement feeding and management-intensive grazing. J. Dairy Sci. 93:1759-1769.

Wylie, A. R. G., S. Woods, A. F. Carson, and M. McCoy. 2008. Periprandial changes in metabolite and metabolic hormone concentrations in high-genetic-merit dairy heifers and their relationship to energy balance in early lactation. J. Dairy Sci. 91:577-586. 